\title{
Evaluation of lead phytoremediation potential of Rumex dentatus: a greenhouse experiment
}

\author{
Muhammad Anwar Sajad ${ }^{1 *}$, Muhammad Saleem Khan ${ }^{1}$, Muhammad \\ Anwar Saleem Khan ${ }^{2}$ and Zaib-Un-Nisa ${ }^{3}$ \\ 1. Department of Botany, Islamia College Peshawar (A Public sector University), Khyber Pakhtunkhwa- \\ Pakistan \\ 2. Department of Zoology, University of Swabi, Khyber Pakhtunkhwa-Pakistan \\ 3. Department of Botany, Women University Swabi, Guloo-Dheri Swabi-Topi Rd, 23430-Pakistan \\ *Corresponding author's email: sajad.khan92@yahoo.com \\ Citation \\ Muhammad Anwar Sajad, Muhammad Saleem Khan, Muhammad Anwar Saleem Khan and Zaib-Un-Nisa. \\ Evaluation of lead phytoremediation potential of Rumex dentatus: a greenhouse experiment. Pure and Applied \\ Biology. Vol. 8, Issue 2, pp1499-1504. http://dx.doi.org/10.19045/bspab.2019.80090
}

\begin{tabular}{llll}
\hline \hline Received: 08/02/2019 & Revised: 04/05/2019 & Accepted: 13/05/2019 & Online First: 17/05/2019 \\
\hline \hline
\end{tabular}

\section{Abstract}

Phytoremediation is a recent approach that employs the use of plants for the removal of pollutants from the environment. This approach is cost effective and environment friendly in comparison of other conventional remediation techniques. A greenhouse experiment was conducted in pots to evaluate the lead phytoremediation potential of Rumex dentatus. Pots were divided into six groups and seeds of the plant were grown in them. Plant parts were analysed for the concentration of $\mathrm{Pb}$. The highest concentration of $\mathrm{Pb}(423.33 \mathrm{mg} / \mathrm{kg})$ was found in the root of group $\mathrm{D}$ plants (grown in $250 \mathrm{ppm} \mathrm{Pb}$-contaminated soil) while the minimum concentration of $\mathrm{Pb}(296 \mathrm{mg} / \mathrm{kg}$ ) was found in the root of group C plants (grown in $100 \mathrm{ppm}$ $\mathrm{Pb}$-contaminated soil). The maximum concentration of $\mathrm{Pb}(467.33 \mathrm{mg} / \mathrm{kg})$ in the shoot of the plants was found in group D plants while its minimum concentration $(85.33 \mathrm{mg} / \mathrm{kg})$ was found in the shoot of group A plants. Bioconcentration factor $(\mathrm{BCF})$ of the plants for $\mathrm{Pb}$ was found higher (18.39) in control group while minimum (0.61) in the plants of group E (0.61). The calculated translocation factor (TF) value of the plants for $\mathrm{Pb}$ was found maximum (1.10) grown in group D pots while its minimum value (0.25) was found in the plants grown in group A soil. The maximum bioaccumulation coefficient (BAC) was 6.74 for the $\mathrm{Pb}$ in the plants of control group while its minimum value $(0.50)$ was found in the plants grown in group $\mathrm{E}$ soil. Only the plant of the $R$. dentatus grown in $270.77 \mathrm{ppm} \mathrm{Pb}$-contaminated soil showed $\mathrm{BCF}, \mathrm{BAC}$ and TF values $>1$ for $\mathrm{Pb}$. Based on $\mathrm{BCF}, \mathrm{BAC}$ and TF values, $R$. dentatus was found feasible for the phytoextraction of $\mathrm{Pb}$ from contaminated soil having $\mathrm{Pb}$ concentration up to $270.77 \mathrm{mg} / \mathrm{kg}$.

Keywords: Phytoremediation; Phytoextraction, Rumex dentatus, Pb-Contaminated soil

Introduction

Heavy metals occurrence in the soil, air, streams and food is an issue due to their detrimental effects on the health of human even at low concentration. Such contaminants in waste water is one of the problems facing humans [1]. Heavy metals are toxic to the life [2]. When the metal bearing waste water is not sufficiently treated over discharge, they enters into the environment and subsequently to the food chain. According to the world health 
organization, one such hazardous metal is lead [1]. It is primarily of interest due to their toxic effects that may cause sub-acute or acute health effects in human beings [3]. Lead is among the common toxic heavy metals disturbing the environment [4]. It's poisoning results from the ingestion of $\mathrm{Pb}$ containing ingredients like paint or water which has stood in lead pipes. Toxicity may also happen from the inhalation of fumes from burning storage batteries. There is no uncertainty that it is extremely toxic to humans. Most of the absorbed $\mathrm{Pb}$ is stored in the brain, blood and bones. Lead colic is characterized by abdominal pain. Due to it impairment of the brain may occur in children and is identified to cause mental retardation, convulsions and even death. It is also documented that $\mathrm{Pb}$ is destructive to the kidney and cause permanent neurological injury [5]. Many health disorders like a rise in blood pressure, disorder of the biosynthesis of haemoglobin and anaemia, behavioural conflicts of children; impulsive behaviour, aggression, hyperactivity and declined fertility of men through sperm damage are due to $\mathrm{Pb}$ pollutants. Through the placenta of the mother it can enters to the foetus and cause severe impairment of the nervous system and to the brains of unborn children. This metal has no known biological role in animals or plants and is extremely toxic to aquatic life and mammals [1].

Lead is a particularly hazardous chemical, as it may accumulate in individual organisms and also in food chains. Phytoremediation is an effective way for the remediation of metal contaminated soil [2]. Thus, lead pollution is a worldwide issue. Current research work was conducted to assess the $\mathrm{Pb}$ phytoremediation Potential of $R$. dentatus grown in $\mathrm{Pb}$ contaminated soil. BCF, BAC and TF of the plants grown in pots were calculated and based on these values the phytoremediation potential of $R$. dentatus for $\mathrm{Pb}$ metal was evaluated.

\section{Materials and methods Experimental design}

A greenhouse experiment was conducted in the botanical Garden of the Department of Botany, University of Malakand. Eighteen pots were used in the experiment. About 6 $\mathrm{kg}$ soil was added into each pot. Pots were divided into 6 group's (Control, A, B, C, D and group $\mathrm{E}$ ). One was control group (three pots) to which no $\mathrm{Pb}$ was added. In the rest of the soil of the five groups different concentration of $\mathrm{Pb}$ (50 ppm, $100 \mathrm{ppm}, 250$ ppm, 500 ppm and 1000 ppm) was added. Three pots were used for each concentration of $\mathrm{Pb}$ in order to significantly assess the uptake potential of $R$. dentatus in control and $\mathrm{Pb}$ - contaminated soil. After the addition of the concentration of $\mathrm{Pb}$ to the pots of five groups, seeds of the plants were sowed in them as well as in control pots. The same water was used for the germination and growth of the plant up to maturity in the green house. Upon maturity the plants were uprooted, labelled and dried for a week in shade. Plant parts (root and shoot) were separated and grinded into powder form through grinder for the preparation of samples for the analysis of $\mathrm{Pb}$.

\section{Lead analysis in the soil}

The background concentration of the $\mathrm{Pb}$ was analysed in the soil, which was used in the experiment. Metal in the soil was determined using standard procedure [6]. Accordingly, 5 gram of soil was taken in a beaker of $100 \mathrm{~mL}$ and $\mathrm{H}_{2} \mathrm{O}_{2}(3 \mathrm{~mL}$ of $30 \%)$ was transferred to it. The soil with hydrogen peroxide was then left as such in the beaker for one hour up to the vigorous reaction stopped. $\mathrm{HCl}(0.5 \mathrm{M})$ of $75 \mathrm{~mL}$ was added into the soil and used hot plate to heat it for about 2 hours. It was cooled and filtered through filter paper. The filtrate obtained was diluted up to $50 \mathrm{ml}$ using distil water and used as sample for the purpose of $\mathrm{Pb}$ determination in them. It was determined in the sample using atomic absorption spectrometry (AAS) in the laboratory of soil sciences, the University of Agriculture. This step was conducted in 
triplicate. Results were shown as mean \pm SD.

\section{Lead analysis in Rumex dentatus}

The plant parts (root and shoot) were initially washed thoroughly with tape $\mathrm{H}_{2} \mathrm{O}$ and then with distilled $\mathrm{H}_{2} \mathrm{O}$ in order to remove soil and dust particles. Oven at $105^{\circ} \mathrm{C}$ was used to dry roots and shoots for 24 hours. They were grinded with the help of electrical grinder. The powder was digested using the standard protocol [7]. Plant part in powder form $(0.5 \mathrm{~g})$ was taken into a beaker of $100 \mathrm{~mL}$ and $65 \%$ concentrated $\mathrm{HNO}_{3}(5 \mathrm{~mL})$ as well as HClO4 (2 mL) were added to it. It was heated using hot plate till the digest became clear. The mixture was cooled and filtered through filter paper. The filtrate was collected in a volumetric flask $(50 \mathrm{~mL})$. It was diluted with distilled $\mathrm{H}_{2} \mathrm{O}$ up to $50 \mathrm{ml}$. The filtrate was used as sample for the determination of $\mathrm{Pb}$ by AAS in the laboratory of soil sciences, the University of Agriculture. As previously mentioned, each step was conducted in triplicate and results were shown as mean \pm SD.

\section{Evaluation of the lead uptake potential of Rumex dentus}

The uptake potential of the $R$. dentatus for $\mathrm{Pb}$ was evaluated by the calculation of $\mathrm{BCF}, \mathrm{TF}$ and BAC. BCF was calculated according to Zhuang et al., [8] while TF using the method of Adesodun et al., [9], and Padmavathiamma and $\mathrm{Li},[10]$. BAC was determined according to the formula used by Cui et al., [11] and Malik et al., [12]. Feasibility of the phytoremediation potential of $R$. dentatus for $\mathrm{Pb}$ was assessed based on BCF, TF and BAC values.

\section{Statistical analysis}

Excel and Graph pad prism 6 was used for statistical analysis.

\section{Results and discussion \\ Concentration of lead in the root and shoot of Rumex dentatus}

The plant of $R$. dentatus was grown in control soil and in different concentration of $\mathrm{Pb}$ contaminated soil $(25 \mathrm{ppm}, 50 \mathrm{ppm}$, $100 \mathrm{ppm}, 250 \mathrm{ppm}$ and 500ppm). The Concentration of $\mathrm{Pb}$ was analysed in the plant parts (Roots and Shoots) grown in different concentration of $\mathrm{Pb}$-contaminated and control soil. The permissible limit of $\mathrm{Pb}$ in soil is $32 \mathrm{mg} / \mathrm{Kg}$ [13]. The concentration of $\mathrm{Pb}$ in the soil used in the experiment was higher than this allowable limit except soil of the control pots. The concentration of lead in $\mathrm{mg} / \mathrm{kg}$ in the roots of the analysed plants was found in the order; Control root (382) > root of group A plants (grown in 25 ppm lead contaminated soil) $(336.67)<$ root of group B plants (grown in $50 \mathrm{ppm}$ lead contaminated soil) (378) > root of group C plants (grown in 100 ppm lead contaminated soil) $(296)<$ root of group D plants (grown in $250 \mathrm{ppm}$ lead contaminated soil) (423.33) > root of group $\mathrm{E}$ plants (grown in $500 \mathrm{ppm}$ lead contaminated soil) (318.67). The concentration of $\mathrm{Pb}$ in shoot of the plants in $\mathrm{mg} / \mathrm{kg}$ was found in the order; Control shoot $(140)>$ group A shoot $(85.33)<$ group B shoot (104) $<$ group C shoot (260) $<$ group D shoot (467.33) > group E shoot (262) (Figure 1). The permissible limit of $\mathrm{Pb}$ in plants recommended by WHO is 2 $\mathrm{mg} / \mathrm{Kg}$ [14]. Results shows that the concentration of $\mathrm{Pb}$ in the roots and shoots of the plants grown in control and $\mathrm{Pb}$ contaminated soil is higher than this permissible limit.

Lead phytoremediation potential of Rumex dentatus

Bioconcentration factor (BCF), translocation factor (TF) and bioaccumulation coefficient (BAC) of the $R$. dentatus grown in control and different concentration of $\mathrm{Pb}$-contaminated soil was calculated. The calculated $\mathrm{BCF}, \mathrm{TF}$ and $\mathrm{BAC}$ values of the plant grown in control and $\mathrm{Pb}$-contaminated soil was used for the evaluation of the plants for the phytoremediation; phytoextraction of $\mathrm{Pb}$ metal. BCF of the plants for $\mathrm{Pb}$ metal was found in the order; Control (18.39) $>$ group A (7.36) > group B (5.34) > group C (2.45) $>$ group D (1.56) $>$ group E (0.61). Sheoran et al., [15] stated that the plants are not feasible for the phytoextraction of metal if $\mathrm{BCF}$ is less than one. Fitz and Wenzel [16] 
demonstrated that plants exhibiting $\mathrm{BCF}$ value less than one are unsuitable for the phytoextraction of metals. BCF of the $R$. dentatus for $\mathrm{Pb}$ was found greater than one except for those grown in $520.77 \mathrm{ppm}$ pbcontaminated soil. The TF values of the same plants for lead were found in the order; Control (0.37) > group A $(0.25)<$ group $\mathrm{B}(0.28)<$ group $\mathrm{C}(0.88)<$ group $\mathrm{D}$ (1.10) $>$ group E (0.82). Both BCF and TF are significant in screening hyperaccumulators for the phytoextraction of metals. The selection and evaluation of plants for the phytoremediation purposes exclusively depend on BCF and TF values [17]. TF value $>1$ indicates the translocation of metals from root to aerial part [18]. According to Yoon et al., [19] only plant species with both TF and $\mathrm{BCF}>$ 1 have the potential to be used for the phytoextraction of metals. TF value of the experimental plant was found $<1$ except for those grown in $270.77 \mathrm{ppm}$ pb- contaminated soil. BAC of the analysed plant for the $\mathrm{Pb}$ metal was found in the order; Control (6.74) $>$ group A (1.87) $>$ group B $(1.47)<$ group C $(2.15)>$ group D $(1.72)>$ group $\mathrm{E}(0.50)$. Only plant species with $\mathrm{BCF}, \mathrm{BAC}$ and $\mathrm{TF}>1$ have the potential for the remediation process [20]. Only the Plant of the $R$. dentatus grown in 270.77 ppm Pb-contaminated soil showed $\mathrm{BCF}, \mathrm{BAC}$ and $\mathrm{TF}$ values greater than one for $\mathrm{Pb}$ metal. The plant $R$. dentatus was found feasible for the phytoextraction of $\mathrm{Pb}$ metal from $\mathrm{Pb}$-contaminated soil which have $\mathrm{Pb}$ concentration up to $270.77 \mathrm{mg} / \mathrm{kg}$. Increase in the concentration of $\mathrm{Pb}$ in the soil was found to decreases the absorption capacity of root of the plant to absorb $\mathrm{Pb}$ from the soil as shown in results. Our findings show similarity to Van der Ent et al., who [21] stated that high metal concentrations in soil could result in a BCF $<1$ (Table 1).

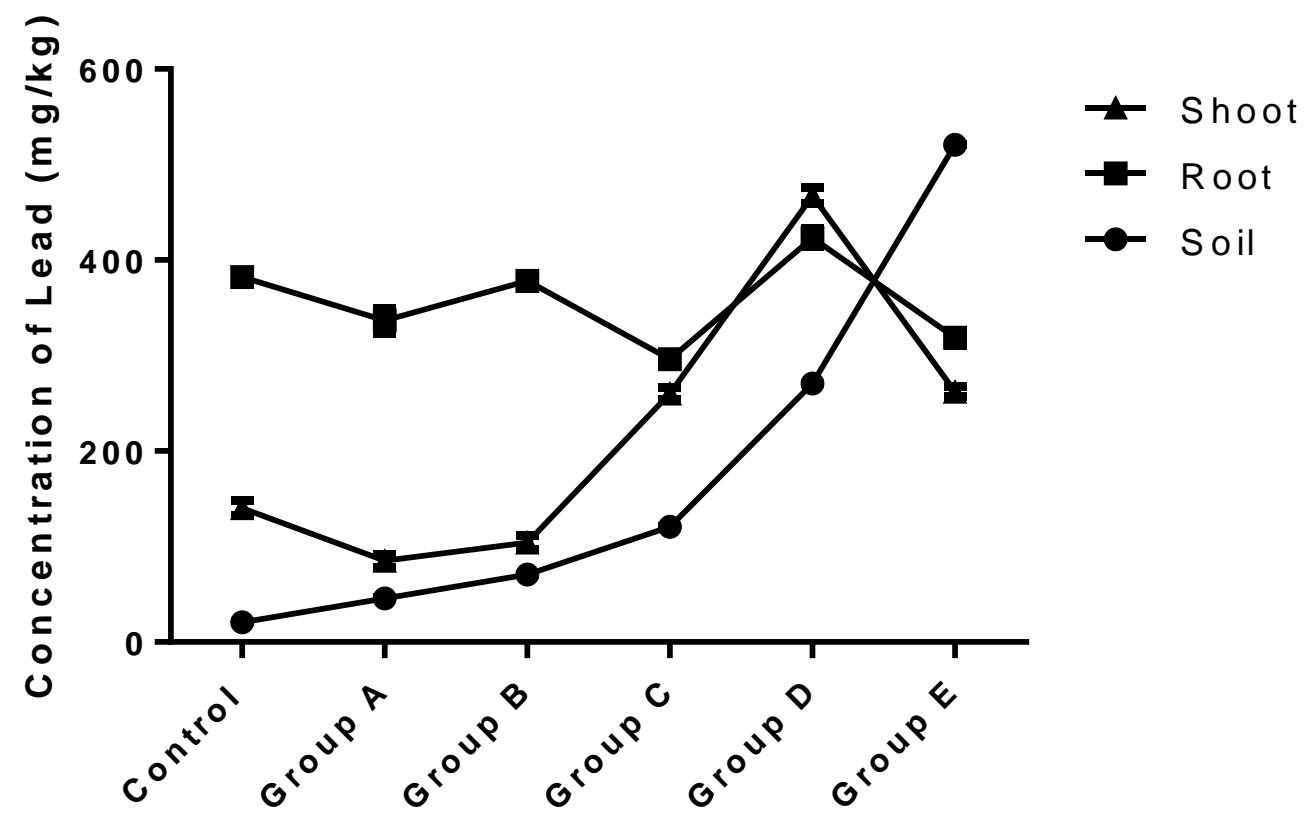

Growth of Rumex dentatus in Control and Lead Contaminated Soil

Figure 1. Lead Uptake potential of Rumex dentatus in Control and contaminated Soil 
Table 1. Bioconcentration factor, translocation factor and bioaccumulation coefficient of Remex dentatus for lead metal

\begin{tabular}{|c|c|c|c|c|c|c|}
\hline \multirow[t]{2}{*}{ Group } & \multicolumn{3}{|c|}{ Concentration of Lead in Soil $(\mathrm{mg} / \mathrm{kg})$} & \multicolumn{3}{|c|}{$\begin{array}{l}\text { Bioconcentration Factor, } \\
\text { Translocation Factor and } \\
\text { Bioaccumulation coefficient }\end{array}$} \\
\hline & $\begin{array}{l}\text { Background } \\
\text { concentration }\end{array}$ & $\begin{array}{l}\text { Concentration } \\
\text { added to the soil }\end{array}$ & $\begin{array}{c}\text { Total } \\
\text { concentration }\end{array}$ & BCF & TF & BAC \\
\hline Control & \multirow{6}{*}{20.77} & 0 & 20.77 & $18.39 *$ & 0.37 & $6.74^{*}$ \\
\hline A & & 25 & 45.77 & 7.36 & 0.25 & 1.87 \\
\hline B & & 50 & 70.77 & 5.34 & 0.28 & 1.47 \\
\hline C & & 100 & 120.77 & 2.45 & 0.88 & 2.15 \\
\hline $\mathbf{D}$ & & 250 & 270.77 & $1.56^{* *}$ & $1.10 * *$ & $1.72 * *$ \\
\hline $\mathbf{E}$ & & 500 & $520.77^{*}$ & 0.61 & 0.82 & 0.50 \\
\hline
\end{tabular}

*Represent maximum value in respective column, ** Represent feasibility of plant for the phytoextraction of $\mathrm{Pb}$

\section{Conclusion}

It is concluded from the experimental work that the highest concentration of $\mathrm{Pb}(423.33$ $\mathrm{mg} / \mathrm{kg}$ ) among the roots of the analysed plants was found in group D while its minimum concentration $(296 \mathrm{mg} / \mathrm{kg})$ was found in the root of group $\mathrm{C}$ plants. The maximum concentration of $\mathrm{Pb}$ (467.33 $\mathrm{mg} / \mathrm{kg}$ ) was found in the shoot of the group D plants while its minimum concentration $(85.33 \mathrm{mg} / \mathrm{kg})$ was found in the shoot of group A plants. The concentration of $\mathrm{Pb}$ in the roots and shoots of the plants grown in control and $\mathrm{Pb}$-contaminated soil was found higher than the permissible limit. BCF of the plants for $\mathrm{Pb}$ metal was found higher (18.39) in control group while minimum (0.61) in the plants of group E (0.61). BCF of the $R$. dentatus for $\mathrm{Pb}$ was found greater than one in all cases except for those grown in $520.77 \mathrm{ppm} \mathrm{Pb}$-contaminated soil. The calculated TF value of the plants for $\mathrm{Pb}$ was found maximum (1.10) grown in group $\mathrm{D}$ pots while its minimum value $(0.25)$ was found in the plants grown in group A soil. TF value of the experimental plant was found $<1$ in all cases except for those grown in $270.77 \mathrm{ppm} \mathrm{Pb}$-contaminated soil. The maximum BAC (6.74) for the $\mathrm{Pb}$ metal was found in the plants of control group while the minimum BAC value (0.50) of the same metal was found for the plants grown in group E soil. Only the Plant of the $R$. dentatus grown in $270.77 \mathrm{ppm} \mathrm{Pb}-$ contaminated soil showed BCF, BAC and
$\mathrm{TF}$ values greater than one for $\mathrm{Pb}$ metal. An increase in the concentration of $\mathrm{Pb}$ in the soil was found to decrease the absorption capacity of root of the plant to absorb $\mathrm{Pb}$ from the soil. Based on BCF, BAC and TF values the plant $R$. dentatus was found feasible for the phytoextraction of $\mathrm{Pb}$ metal from $\mathrm{Pb}$-contaminated soil which have $\mathrm{Pb}$ concentration up to $270.77 \mathrm{mg} / \mathrm{kg}$.

\section{Authors' contributions}

Conceived and designed the experiments: MS Khan \& MA Sajad, Performed the experiments: MA Sajad, Analyzed the data: MS Khan \& MA Sajad, Contributed materials/ analysis/ tools: MS Khan \& MA Sajad, Wrote the paper: MA Sajad, MAS Khan \& ZU Nisa.

\section{Acknowledgment}

Authors are thankful to the chairman, Department of Soil Sciences, the University of Agriculture, Peshawar Pakistan for providing AAS (Atomic Absorption spectrophotometry) facility in their laboratory.

\section{References}

1. WHO (World Health Organisation) (1984). Guideline for drinking water quality, Recommendation. 1st, vol.1, World Health Organization, Geneva.

2. Sajad MA, Khan MS, Ali H \& Nisa ZU (2018). Lead phytoremediation potential of sixty-one plant species: An open field survey. Pure Appl. Biol.

3. EPA (Environmental protection Agency) USA (1987). update \# 2 to Quality 
criteria for water, May 1,1987 office of water Regulation and standards criteria and standards Division, Washington D.C.

4. Alloway BJ \& Ayres DC (1993). Chemical Principles of Environmental Pollution, 1st ed. Blackie Academic and Professional, London.

5. Snyder RB, Wuebbles DJ, Pearson JE \& Ewing BB (1971). A Study of Environmental Pollution by Lead. Institute for Environmental Study, State of Illinois, IIEQ, Document No: 717. United state of American.

6. Sharidah MMA (1999). Heavy metals in mangrove sediment of united Arab Emirates Shoreline (Arab Gulf). Water Air Soil Pollut 116(3): 523-534.

7. Awofolu OR (2005). A survey of trace metals in vegetation, soil, and lower animals along some selected major roads in metropolitan city of Lagos. Environ Monit Assess 105(1):431 447.

8. Zhuang P, Yang QW, Wang HB \& Shu WS (2007). Phytoextraction of heavy Metals by eight plant species in the field. Water, Air and Soil Pollut 184(1): 235242.

9. Adesodun JK, Atayese MO, Agbaje TA, Osadiaye BA, Mafe OF \& Soretire AA (2010). Phytoremediation potentials of sunflowers (Tithonia diversifolia and Helianthus annus) for Metals in soils contaminated with zinc and lead nitrates. Water, Air and Soil Pollut 207(1): 195201.

10. Padmavathiamma PK \& Li LY (2007). Phytoremediation technology: Hyperaccumulation metals in plants. Water, Air and Soil Pollut 184(1): 105126. 13

11. Cui S, Zhou Q \& Chao ZY (2007). Potential hyper-accumulation of $\mathrm{Pb}, \mathrm{Zn}$, $\mathrm{Cu}$ and $\mathrm{Cd}$ in endurant plants distributed in an old smeltery, northeast China. Environ Geol 51(6): 1043-1048.

12. Malik RN, Husain SZ \& Nazir I (2010). Heavy Metal Contamination and Accumulation in Soil and Wild Plant Species from Industrial Area of
Islamabad, Pakistan. Pak J Bot 42(1): 291-301.

13. Nergus Y (2002). Problems of health and environmental geochemistry. Thesis, Hamdard University, Karachi, Pakistan. 85-104.

14. Nazir R, Khan M, Masab M, Rehman HU, Rauf NU, Shahab S, Ameer N, Sajed M, Ullah M, Rafeeq M \& Shaheen $Z$ (2015). Accumulation of Heavy Metals ( $\mathrm{Ni}, \mathrm{Cu}, \mathrm{Cd}, \mathrm{Cr}, \mathrm{Pb}, \mathrm{Zn}, \mathrm{Fe})$ in the soil, water and plants and analysis of physico-chemical parameters of soil and water Collected from Tanda Dam kohat. J Pharm Sci \& Res 7(3): 89-97.

15. Sheoran V, Sheoran A \& Poonia P (2011). Role of hyperaccumulators in phytoextraction of metals from contaminated mining sites: a review. Crit Rev Environ Sci Technol 41(2): 168214.

16. Fitz WJ \& Wenzel WW (2002). Arsenic transformation in the soil- rhizosphereplant system, fundamentals and potential application of phytoremediation. $J$ Biotechnol 99: 259-278.

17. Wu J, Liu Y, Tang L, Zhang FL \& Chen F (2011). A study on structural features in early flower development of Jatropha curcas L. and the classification of its inflorescences. Afr J Agric Res 6(2): 275-284.

18. Jamil S, Abhilash PC, Singh N \& Sharma PN (2009). A potential crop for phytoremediation of coal fly ash. $J$ of Hazard Mater 172(1): 269-275.

19. Yoon J, Cao X, Zhou Q \& Ma LQ (2006). Accumulation of $\mathrm{Pb}, \mathrm{Cu}$ and $\mathrm{Zn}$ in native plants growing on contaminated Florida site. Sci of the total Environ 368(2-3): 456-464.

20. Nazir A, Malik RN, Ajaib M, Khan N \& Siddiqui MF (2011). Hyperaccumulators of heavy metals of industrial areas of Islamabad and Rawalpindi. Pak J Bot 43(4): 19251933.

21. Van der Ent A, Baker AJM, Reeves RD, Pollard AJ \& Schat H (2013). Hyperaccumulators of metal and metalloid trace elements: facts and fiction. Plant Soil 362: 319-334. 